\title{
Determination of Urinary Methyl Hippuric Acid Using Shimadzu UV-Visible Spectrophotometer Among Petroleum Employees
}

\author{
Vidya Gowdappa Doddawad ${ }^{1 *}$, B.M. Gurupadayya ${ }^{2}$, Shivananda S', Vidya CS ${ }^{3}$, Azhar Mohammed ${ }^{4}$, Bhuyan L ${ }^{5}$
}

\begin{abstract}
Vidya Gowdappa Doddawad ${ }^{1, *}$, B.M. Gurupadayya ${ }^{2}$, Shivananda $\mathrm{S}^{1}$, Vidya $\mathrm{CS}^{3}$, Azhar Mohammed ${ }^{4}$, Bhuyan L
\end{abstract}

IJSS Dental College and Hospital, Mysuru 570022, INDIA.

2JSS College of Pharmacy, Mysuru - 570015, INDIA. 3JSS medical College and Hospital, Mysuru3JSS medical Coll

570022, INDIA.
${ }_{4}^{4}$ A.B. Shetty Memoi

${ }^{4}$ A.B. Shetty Memorial Institute of Dental Sciences, Mangalore, INDIA.

${ }^{5}$ Kalinga Institute of Dental Sciences,

Bhubaneswar, INDIA.

\section{Correspondence}

Vidya Gowdappa Doddawad

JSS Dental College and Hospital, Mysuru 570022, INDIA.

Phone no: +91 9343830621/9343322433

E-mail: drvidyagd@gmail.com

History

- Submission Date: 13-06-2021.

- Review completed: 14-07-2021;

- Accepted Date: 30-7-2021

DOI : 10.5530/pj.2021.13.161

Article Available online

http://www.phcogj.com/v13/i5

Copyright

(C) 2021 Phcogj.Com. This is an openaccess article distributed under the terms of the Creative Commons Attribution 4.0 International license.

\begin{abstract}
Xylene is a significant part of petroleum and a broadly considered as a natural impure material. About $98 \%$ of Xylene is extracted from the petrochemical and petrol refining factories. It is one of the major genotoxicant part in petroleum, which may initiate various diseases but malignancy is questionable. Taking into consideration, we intend to identify the urinary methyl hippuric acid level which is metabolic product of xylene among petroleum station employees as well as in healthy persons. Aims and Objectives: To identify the occupational exposure of xylene in petrol station employees by assessing urinary methyl hippuric acid level. To determine and compare the level of urinary methyl hippuric acid among healthy individuals and petrol station employees. Materials and Methods: Urine samples were collected from 30 healthy individual (control) and 30 petroleum employees (case) working in petroleum station who are above 18 years of age. The urinary methyl hippuric acid (MHA) level was analysed by using Shimadzu UV-Visible Spectrophotometer method. Results: The urinary Methyl hippuric acid level was significantly higher in petroleum station employees than in healthy individuals $(p<0.001)$. Conclusion: The urinary MHA level is a helpful tool to identify the occupational exposure of people who work in petrol and petroleum product. Subsequently, our investigation accentuates that proper precautionary measure and efficiently bio-observing should be taken among petrol station employees which will assist with reducing their likely degrees of risk related with the occupation. It might start the cancer-causing disease through the cellular DNA changes and induce genotoxic effects.
\end{abstract}

Key words: Xylene, Occupational Exposure, Urine Methyl Hippuric Acid Level, UV Spectrophotometry.

\section{INTRODUCTION}

Wellbeing is exceptionally valuable and the workplace assumes a significant part in one's wellbeing. Air, noise, heat and radiation are the primary resources of natural contamination particularly in metropolitan areas. ${ }^{1}$

A numerous of employees who were exposed to different dangerous material or things in a several type of work place settings, among which petrol and its product is one among them. ${ }^{2}$ There are many toxic effects may be involved due to exposure of petroleum products or volatile organic compound (VOCs) like benzene, toluene, ethylene and xylene. ${ }^{3}$

Petrol is a mixture of various chemical substances in which xylene is one among them and it considered as genotoxic agent. Exposure to petroleum products is classified by the International Agency for Research on Cancer as Group-2A ('presumably') cancer-causing agent to people, chiefly based on recognised carcinogenicity. ${ }^{3}$ The presence of xylene in petroleum is considered as the occupational exposure to these station workers. ${ }^{4}$

Xylene is a colourless, combustible fluid which found in both natural items like coal tar and oil and furthermore in synthetic items like inks, insect sprays, and paints. Xylene is used as a solvent to make other chemical substances. Individuals may be get exposed to xylene through various forms including breathing air, especially in the place were working in petrol plants or petroleum stations. ${ }^{5}$
The mechanism(s) of xylene as a cancer-causing agent has not yet completely known but the literature have well recorded that it acts as a genotoxic agent causing cancer. Spleen, oral mucosa, bone marrow and peripheral smear have shown Cytogenetic damages like structural aberrations, micronuclei $(\mathrm{MN})$ and sister chromatid exchanges (SCEs), in mice which is exposed to petrol especially benzene but it's not manifest in people. Among all the cytogenetic biomarkers, micronuclei have been broadly used to measure effect of chromosome to genotoxic agents. ${ }^{6}$

Methyl hippuric acid is a main biproduct of xylene and thus its level in urine can be utilized to screen the exposure of workers in petrol station. ${ }^{5}$ Although metabolite of xylene is available at low level in urine of few people, attempting to locate some advance method or technique of direct measurement of trace element from natural and artificial pollutant. It can be a reasonable elective approach to defeat the issues which may affect the health and may connect with the metabolite (methyl hippuric acid) of xylene in urine. $^{7}$

Gas station employees are persistently exposed to petrol and its products through breathing during vehicle refueling. Taking into consideration that genotoxic hazards may induced by occupational exposure like petrol station. Thus, our examination means to explore the urinary methyl hippuric acid level in both healthy persons and gas station employees utilizing Shimadzu UVspectrophotometric method.

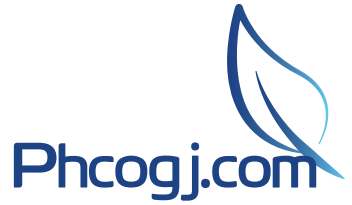

Cite this article: Doddawad VG, Gurupadayya BM, Shivananda S, Vidya CS, Mohammed A, Bhuyan L. Determination of Urinary Methyl Hippuric Acid Using Shimadzu UV-Visible Spectrophotometer Among Petroleum Employees. Pharmacogn J. 2021;13(5): 1277-1281. 


\section{MATERIALS AND METHOD}

The present study was conducted in Mysuru and the cases will be selected from the petrol station, based on the inclusion and exclusion criteria. The control i.e., healthy individuals were who were not exposed continuously to petrochemical product. Both case and controls were taken after given their written consent to participate in the present study.

\section{Inclusion criteria}

- Persons giving their written consent to participate in the study.

- Male employees who are above 18 years of age

- Participant working in the Mysuru city limits.

- Workers who are working in shifts not less than $8 \mathrm{hrs}$.

- Worker who are working in petrol station for a period of 5ys or above.

- Workers should not have the habit of consuming any form of tobacco/alcohol.

\section{Exclusion criteria}

- Person with history of any systemic condition or disease.

- Person with history of any chemotherapy/ surgery/ radiation therapy.

The urine samples were collected from both 30 healthy individual (control) and 30 petroleum station employees (case) who are working in petroleum station and it was collected in two times like before work shift starts and after a work shift complete. Shimadzu UVVisible Spectrophotometer analysis was used to analyse the urinary methyl-hippuric acid (MHA) level. (Figure 1). Shimadzu UV-Visible Spectrophotometer analysis were carried out on a UV- vis Shimadzu UV-mini 1800 spectrophotometer (Shimadzu-Japan) in a $1 \mathrm{~cm}$ quartz cubette. The wavelength $205 \mathrm{~nm}$ was used for the quantitation of methyl hippuric acid measurement against water as a blank. The obtained data were entered in the excel sheet and statistical analysis methods were applied using SPSS.22.

\section{RESULT}

In the present study, the urinary MHA level was in cases was found to be higher compare to controls as shown in Table 1 and Graph 1. Before work shift, the urinary MHA level in cases, was highly significant compare to after shift of work, as shown in Table 2.

Similarly, the urinary MHA level before and after work shift, were shown as non-significant i.e no much variation in the level of urinary

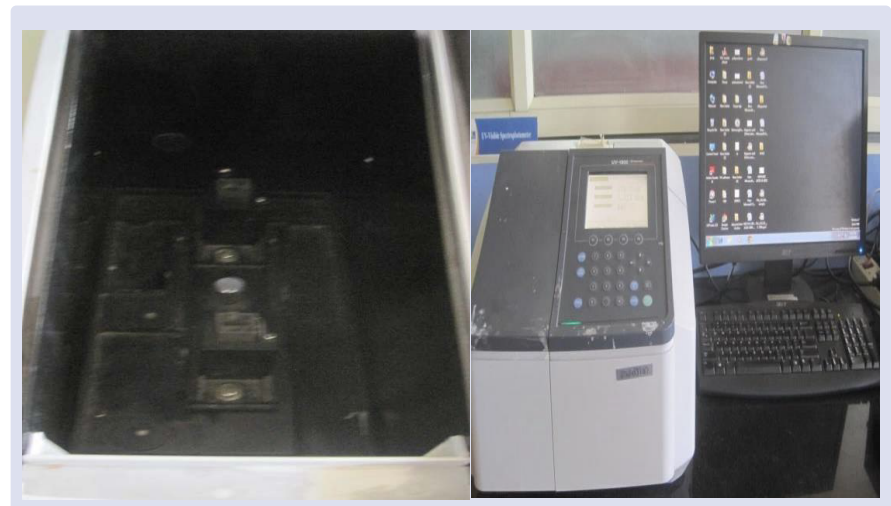

Figure 1: Shimadzu UV-Visible Spectrphotometer with quartz cuvettes and digital display.

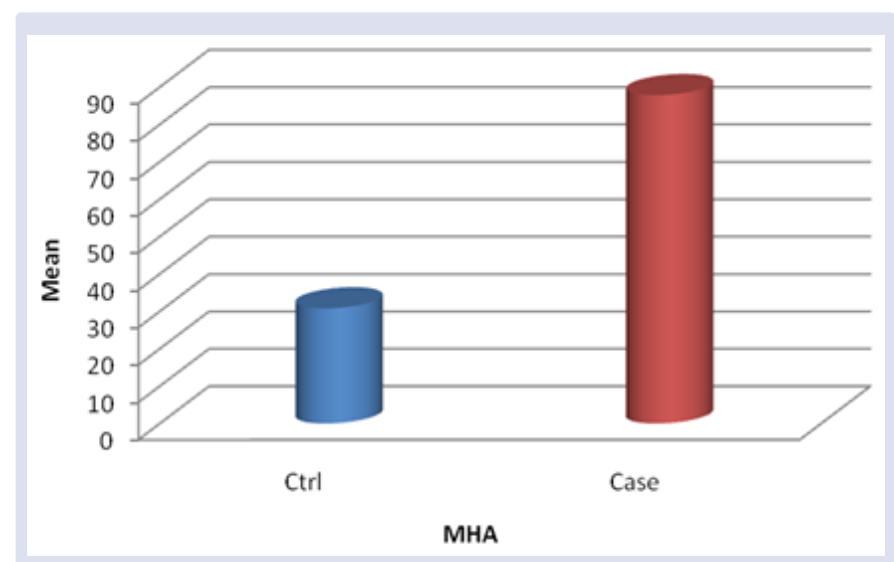

Graph 1: Showing the level of urinary MHA in both Cases and Controls.

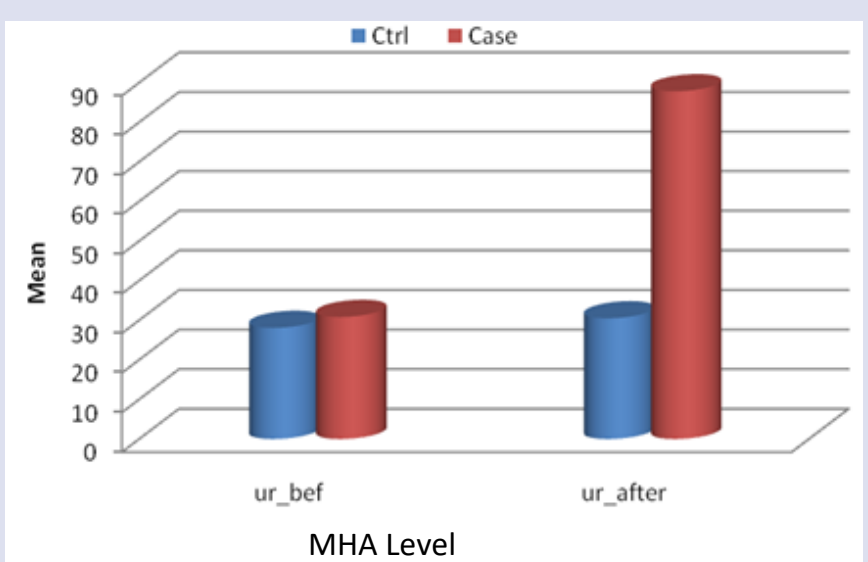

Graph 2: Comparison of urinary MHA level in cases and controls before and after shifts of work.

Table 2: The mean, SD value of Urinary MHA level in both cases and controls.

\begin{tabular}{lllll}
\hline & Group & Mean & SD & Inference \\
\hline $\begin{array}{l}\text { Urinary MHA } \\
(\mu \mathrm{g} / \mathrm{ml})\end{array}$ & Controls & 30.8 & 7.42038 & Highly \\
Cases & 87.8 & 29.18441 & Significant \\
\hline
\end{tabular}

Table 2: Urinary MHA level in Cases before and after shift of work.

\begin{tabular}{|c|c|c|c|c|}
\hline Variable & Group & Mean & SD & Inference \\
\hline \multirow{2}{*}{$\begin{array}{l}\text { Urinary MHA } \\
(\mu \mathrm{g} / \mathrm{ml})\end{array}$} & $\begin{array}{l}\text { Cases Before } \\
\text { shift }\end{array}$ & 30.833 & 7.39680 & \multirow{2}{*}{$\begin{array}{l}\text { Highly } \\
\text { Significan }\end{array}$} \\
\hline & $\begin{array}{l}\text { Cases After } \\
\text { shift }\end{array}$ & 87.8333 & 29.18441 & \\
\hline
\end{tabular}

Table 3: Urinary MHA level in Controls before and after shift of work.

\begin{tabular}{lllll}
\hline Variable & Group & Mean & SD & Inference \\
\hline $\begin{array}{l}\text { Urinary } \\
\text { MHA }\end{array}$ & $\begin{array}{l}\text { Controls } \\
\text { Before shift }\end{array}$ & 28.0667 & 2.21178 & \\
$(\mu \mathrm{g} / \mathrm{ml})$ & $\begin{array}{l}\text { Controls After } \\
\text { shift }\end{array}$ & 30.5000 & 1.85231 & $\begin{array}{l}\text { Non } \\
\text { Significant }\end{array}$ \\
& & & &
\end{tabular}

MHA level among control population as shown in Table 3. Comparison of urinary MHA level in both cases and controls, before and after shifts of work is showing in Graph 2.

\section{DISCUSSION}

Xylene is a significant element of petrol and considered as a widely distributed environmental pollutant. About $98 \%$ of Xylene is extracted 
from the petrochemical and petroleum refining factories. These petrol station workers will expose to these petroleum products continuously through vehicle refuelling. In this manner, xylene will get expose in other settings like people who were working in manufacturing paints, factories and other modern settings. ${ }^{8}$ When people get presented to one of the major genotoxicant like xylene have been related with an acute or chronic disease or any malignancy depending upon amount, type and duration of exposure. ${ }^{9}$

Petrol station workers are chronically exposed to petroleum derivatives primarily through inhalation of the volatile fraction of petrol during vehicle refuelling. Therefore, occupational exposure to xylene in humans generally takes place in factories, refineries; petrol refuelling and other industrial settings. ${ }^{8}$ When humans get exposed to one of the major genotoxicant like xylene have been associated with a range of acute/chronic diseases/ cancer depending upon the concentration and time of exposure. ${ }^{9}$

Methyl hippuric acid is a main metabolite of xylene and consequently its level in urine can be utilized to screen the petrol station workers about their exposure. ${ }^{5}$

The current research work consists of total 60 male participant of age above $18 \mathrm{yr}$ in which 30 petrol station workers (case) working in petrol station past 5 years and 30 healthy people (control) with no known petrochemical product exposure. All the participants were selected based on the inclusion and exclusion criteria. Urine samples was collected from all the participant at two times in a day i.e before work shift starts and after work shift. Collected urine samples was analysed for MHA level by using UV-spectrophotometer.

In our current study, the urinary MHA level was appeared to be more in petrol station workers population $(87.8 \mu \mathrm{g} / \mathrm{ml})$ than healthy individuals $(30.8 \mu \mathrm{g} / \mathrm{ml})$. Similar to our study, the results was matching with other studies who have done estimation of urinary MHA level in petrol station workers like Celik An et al. (2003), ${ }^{3}$ Singaraju et al. (2012), ${ }^{7}$ Koschsorur et al. (2000), ${ }^{10}$ Verma et al. (2001), ${ }^{11}$ Hein et al. (1989)..$^{12}$

In the current study, the urinary MHA level of petrol station workers showed higher in MHA level at end of work shift when compare to the beginning of work shift. Similar to our results, Engstrom K et al. $(1978)^{13}$ who concluded that the level methylhippuric acid was high at the work end compare to the work beginning.

As our study exhibiting the results, the urinary MHA level is a helpful element to identify the petrol and its product exposure which is environmental pollutant. Therefore, we need to investigate and identify the xylene effect on human health at an advanced molecular level with a larger sample size.

Xylene is considered as a carcinogenic agent which may initiate and harm the cell at gene level. Hence, from our study we conclude that petrol station workers need a appropriate safety and security items like apron, mouth mask, goggles to damage or minimise the health risk which are associate with it

\section{CONCLUSION}

The risks of xylene are very much recorded; however, the substitutes are not all that completely assessed. It may not be a great idea to get expose to petroleum product on every day at a bigger the volume. One should know these petroleum products are the primary health hazardous pollutant that is answerable for the genotoxic effect. The outcome from our study, we recommended that reduce the exposure to these as much as possible in working environments. It is better to control and reduce the exposure to these products by educating the workers for their wellbeing. Subsequently, the gas station workers should utilize an appropriate individual protective gear like goggles, apron, mouth mask or organic respirator etc. so that these may prevent the dangerous effect of xylene on individual wellness.

\section{FUNDING}

The author would like to thank the JSS Academy of Higher Education for funding the doctoral dissertation research grant

\section{AUTHORS CONTRIBUTIONS}

All the authors have contributed equally.

\section{CONFLICS OF INTERESTS}

Declared none.

\section{REFERENCES}

1. Satapathy DM, Behera TR, Tripathy RM. Health status of traffic police personnel in Brahmapur City. Indian Journal of Community Medicine. 2009; 34(1): 71-72.

2. Benites $\mathrm{Cl}$, Amado LL, Vianna RAP, Martino RMG. Micronucleus test on gas station attendants. Genet Mol Res. 2006; 5(1): 45 - 54.

3. Celik A, Cavas T, Ergene GS. Cytogenetic bio-monitoring in petro station attendant's micronucleus test in exfoliated buccal cells. Mutagenesis. 2003; 18 (5):417- 21.

4. World Health Organization. Preventing disease through healthy environments exposure to benzene: A major public health concern. 2010. Available from: www.who.int/ipcs/features/benzene.

5. HR Heidari, SJ Shahtaheri, F Golbabaei, M Alimohammadi, A RahimiFroshani. Trace Analysis of Xylene in Occupational Exposures Monitoring. Iranian Journal Publ Health. 2009; 38(1) :89-99.

6. Ranaldi R, Bassani B, Villani P, Lombardi CC, Tanzarella C Pacchierotti F. Measurement and characterization of micronuclei in cultured primary lung cells of mice following inhalation exposure to benzene. Mutagenesis.1998; 13 (5): 453-60.

7. Singaraju M, Singaraju S, Parwani RN, Wanjari SP. Cytogenetic biomonitoring in petrol station attendants: A micronucleus study. J Cytol. 2012; 29(1): 1-5

8. Rajkokila K, Shajithanoop S, Usharani MV. Nuclear anomalies in exfoliated buccal epithelial cells of petrol station attendants in Tamilnadu, South India. J Med Genet Genome. 2010; 2(2): 24-28.

9. P Arul, Smitha shetty, Suresh masilamani, C Akshatha, BJ Naveen Kumar. Evaluation of micronucleus in exfoliated buccal epithelial cells using liquid based cytology preparation in petrol station workers. Indian J Med Paediatr Oncol. 2017; 38(3): 273-276.

10. Khoschsorur GA and Peter W. Rapid determination of benzene metabolites phenol and p-cresol in urine of petrol station workers by gas chromatography. Anal Sci. 2000; 16: 589-591.

11. Verma Y, Rana VS. Biological Monitoring of Exposure to Benzene in Petrol Pump Workers and Dry Cleaners. Ind Health. 2001; 39(4): 330-3.

12. Hein R, Aung TB, Lwin O, Zaidi HS. Assessment of occupationa benzene exposure in petrol filling stations at Rangoon. Ann Occup Hyg. 1989; 33 (1): 133-6.

13. Engstrom K, Husman K, Pfaffli P, Riihimaki V. Evaluation of occupational exposure to Xylene by Blood, Exhaled air and Urine Analysis. Scand journal work environment and health.1978; 4:114121 


\title{
GRAPHICAL ABSTRACT
}

\section{DETECTION OF METABOLIC PRODUCT OF XYELE USING SHIMADZU UV-VISIBLE SPECTROPHOTOMETER.}

\author{
Metabolite of xylene \\ Methyl hippuric acid \\ Seen in urine
}

Urine samples were collected from

30 healthy individual (control) who

are above 18 years of age.

$$
\begin{aligned}
& \text { Urine samples were collected from } 30 \text { petroleum } \\
& \text { employees (case) working in petroleum station } \\
& \text { who are above } 18 \text { years of age. }
\end{aligned}
$$

\section{ABOUT AUTHORS}

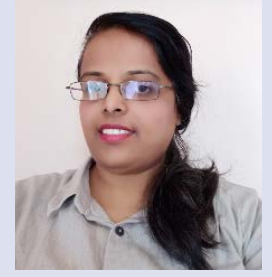

Dr. Vidya Gowdappa Doddawad.

Associate professor

Department of oral pathology and microbiology, JSS Dental College and Hospital

(A Constituent College of JSS Academy of Higher Education \& Research) Mysuru-570022

Major contributor in writing the concept and planning of the study

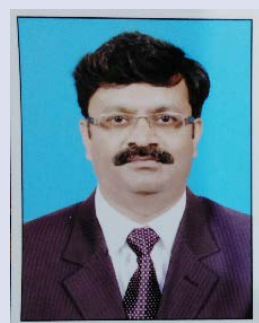

DR. B.M. Gurupadayya

Professor

Department of Pharmaceutical Chemistry,

JSS College of Pharmacy,

(A Constituent College of JSS Academy of Higher Education \& Research)

Mysuru-570 015

Conducted the study in the laboratory

Dr. Shivananda S

Associate professor

Department of oral and maxillofacial surgery

JSS Dental College and Hospital

(A Constituent College of JSS Academy of Higher Education \& Research)

Mysuru-570022

He collected and transferred the samples from study area to lab 


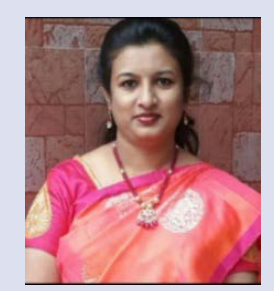

\section{Dr.Vidya CS}

Professor

Department of Anatomy

JSS Medical College and Hospital.

(A Constituent College of JSS Academy of Higher Education \& Research)

Mysuru-570022

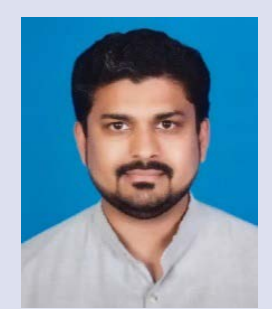

Analysed and interpreted the results of study

Dr Azhar Mohammed

Lecturer

Department of Orthodontics and Dentofacial Orthopaedics

A.B. Shetty Memorial Institute of Dental Sciences, Mangalore.

(Nitte deemed to be University)

Made the study design, idea and collected the patients' data

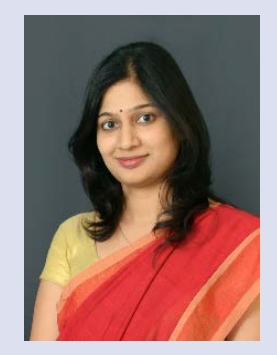

Dr. Lipsa Bhuyan

Reader

Department of Oral and Maxillofacial Pathology,

Kalinga Institute of Dental Sciences,

Bhubaneswar

Drafting, conception and approved the final version of the manuscript

Cite this article: Doddawad VG, Gurupadayya BM, Shivananda S, Vidya CS, Mohammed A, Bhuyan L. Determination of Urinary Methyl Hippuric Acid Using Shimadzu UV-Visible Spectrophotometer Among Petroleum Employees. Pharmacogn J. 2021;13(5): 1277-1281. 